\title{
Invisible Communities and
} Their Visible Cameras

\section{The Landscape Photography of the Chinese}

\section{Camera Club of South Africa}

\author{
Malcolm Corrigall
}

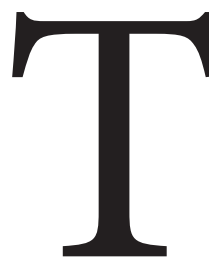

he Chinese Camera Club of South Africa (CCCSA), sometimes known as the Chinese Camera Club of Johannesburg, was a group of Chinese South African photographers who were at their most active during the 1950 s and 196os. Despite their small numbers and the discrimination and exclusion they suffered as Chinese South Africans, this group of tenacious and dedicated photographers achieved success and recognition in photographic networks at home and abroad. I will concentrate on one aspect of their output-namely, landscape photography-to argue that individual members of the CCCSA used photography to visualize a sense of belonging to both China and South Africa. ${ }^{1}$ By giving visual expression to multiple configurations of identity, which were simultaneously local and international, club members actively contested their treatment by the apartheid state. In particular, I consider how members of the club photographed the South African landscape in ways which drew on conventions associated with Chinese landscape painting. I will argue that this expressed notions of pride and belonging that counteracted the humiliation and discrimination suffered by Chinese South Africans during apartheid. I also consider how club members mastered local South African approaches to landscape photography to communicate their attachment to Johannesburg and South Africa, as well as to prove their equality with white-dominated camera clubs and photographic societies.

Darren Newbury (2013:231) has astutely observed the "need to consider a wider range of photographic practices than have typically been given attention in histories of South African photography." Newbury (2013:227) suggested that such research can reveal how "ordinary South Africans" used photography to express "dreams and aspirations" that were curtailed by the apartheid system. ${ }^{2}$ As its achievements show, the CCCSA functioned in exactly this way: it allowed photographers, individually and collectively, to represent themselves and their communities in ways which transcended the restrictive identities imposed upon them by the hierarchies of racial classification embedded within the apartheid nation state.

\section{CAMERA CLUBS, PICTORIALISM, AND EXISTING SCHOLARSHIP}

A number of individual CCCSA members, such as the club president, Jack Ho, identified themselves as pictorialist photographers. ${ }^{3}$ Furthermore, the CCCSA was part of a domestic and international network of camera clubs and photographic societies whose history was intrinsically linked to the trajectory of pictorialism as a movement and for whom pictorialist approaches and aesthetics continued to exert a strong influence in the 1950 s and 196os, alongside other coexisting photographic genres and practices. Pictorialism, a photographic movement that first emerged in late nineteenth century Europe, developed through international networks of photographic societies, camera clubs, and salon exhibitions and remained influential throughout the early and mid twentieth century. Central to pictorialism was the idea of the photograph as a vehicle for personal and artistic expression and the idea of the hand-printed photograph as a unique "artwork" (Nordström and Wooters 2008:48).

Kathleen Grundlingh (1999:243-44; 2001:34) has argued that the development of pictorialism as a movement in South Africa closely mirrored international trends. Dr. A.D. "Kin" Bensusan, a prominent Johannesburg-based pictorialist and founder of the Photographic Society of South Africa, also emphasized the movement's international links in his descriptive and chronological account of the history of pictorialism in South Africa (1966:86-98). However, recent scholarship has suggested that 


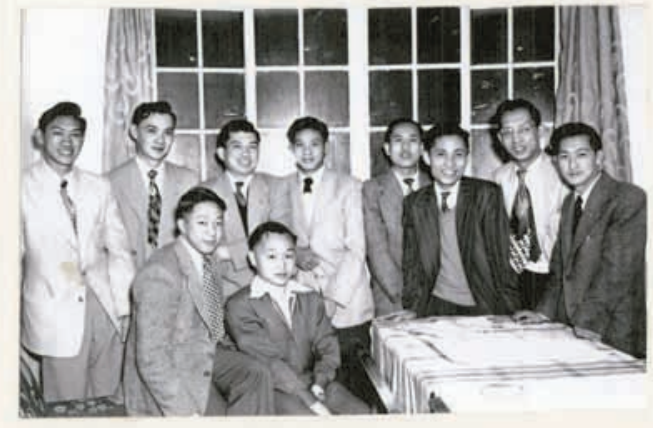

Ting; fhot Hewe
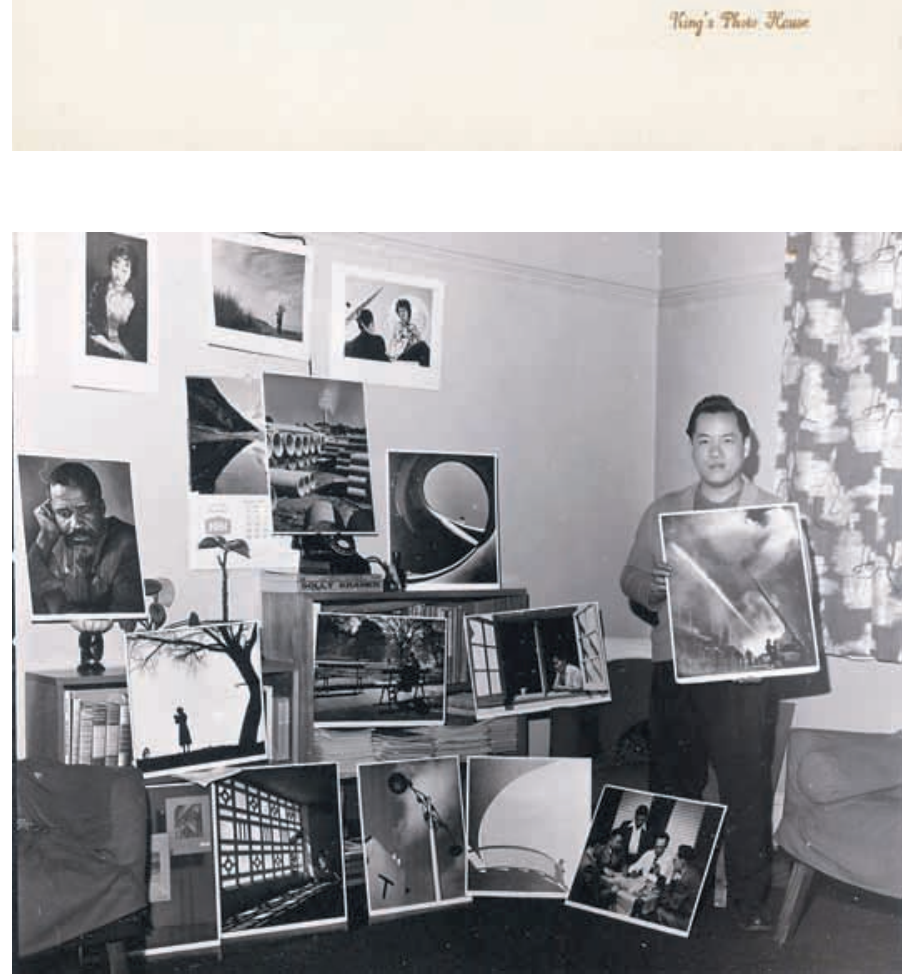

pictorialism in South Africa was as much shaped by local factors. Phindeswa Mnyaka has researched the work of prominent pictorialist photographer Joseph Denfield (1911-1967), who was an active member of the East London Photographic Society in South Africa. Mnyaka (2014) has highlighted how Denfield's work-and, by extension, wider trends in South African pictorialism - were shaped by discourses of "native administration" and shifting modes of political administration. Michael Godby, in his research on landscape photographs produced by pictorial photographers and camera clubs in the early half of the twentieth century, has argued that pictorialists sought to capture the grandeur and beauty of the South African landscape in ways which reflected early twentieth century conceptions of patriotism and white South African identity (Godby 2013a:159). Elsewhere, Godby (2013b:49-50) has examined the peculiarly South African pictorialist genre of "Native Studies." This genre was defined by its sentimental renderings of black South African subjects, which eschewed the anthropological imperatives of previous approaches to photographing "African" life in the nineteenth and
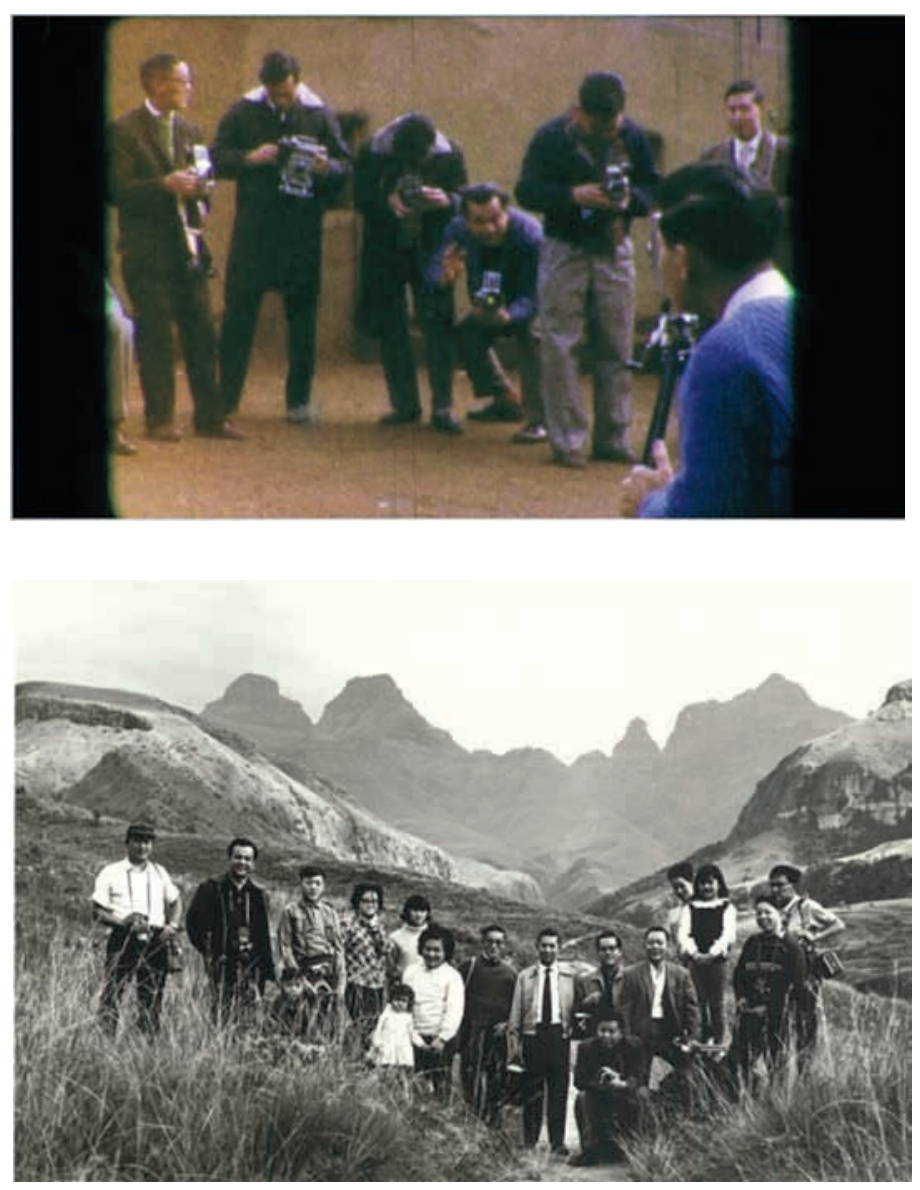

(clockwise from top left)

1 Inaugural meeting of the Chinese Camera Club of South Africa, 1952. Jack Ho is in the front row on the left.

Photo: (C) Cecil King. Courtesy of Jack Ho and Lorna Sing

2 Still from an $8 \mathrm{~mm}$ cine film taken during an outing to the Northern Transvaal, ca. 1960-1964. Photographer unknown. Photo: Courtesy of Edmund Lang

3 Photograph of a Chinese Camera Club of South Africa Outing to the Drakensburg Mountains. Date and photographer unknown.

Photo: Courtesy of Teddy Lai

4 Chuck Ho, a member of the Chinese Camera Club of South Africa, displays some of his prints. Date and photographer unknown.

Photo: Courtesy of Edmund Lang

twentieth century. Godby's research highlights how pictorialism developed differently in South Africa, just as it had differing trajectories in other parts of the world. As the pictorialist genre of "Native Studies" demonstrates, this was due, in part, to its dialectical relationships with existing photographic genres and local ideas and practices.

\section{THE CHINESE SOUTH AFRICAN COMMUNITY IN}

\section{0s AND 1960s SOUTH AFRICA}

The members of the CCCSA were part of a community which descended from free immigrants who came to South Africa from southern China from the 1870 on onwards. These immigrants faced an environment of racial discrimination and exclusion. The 


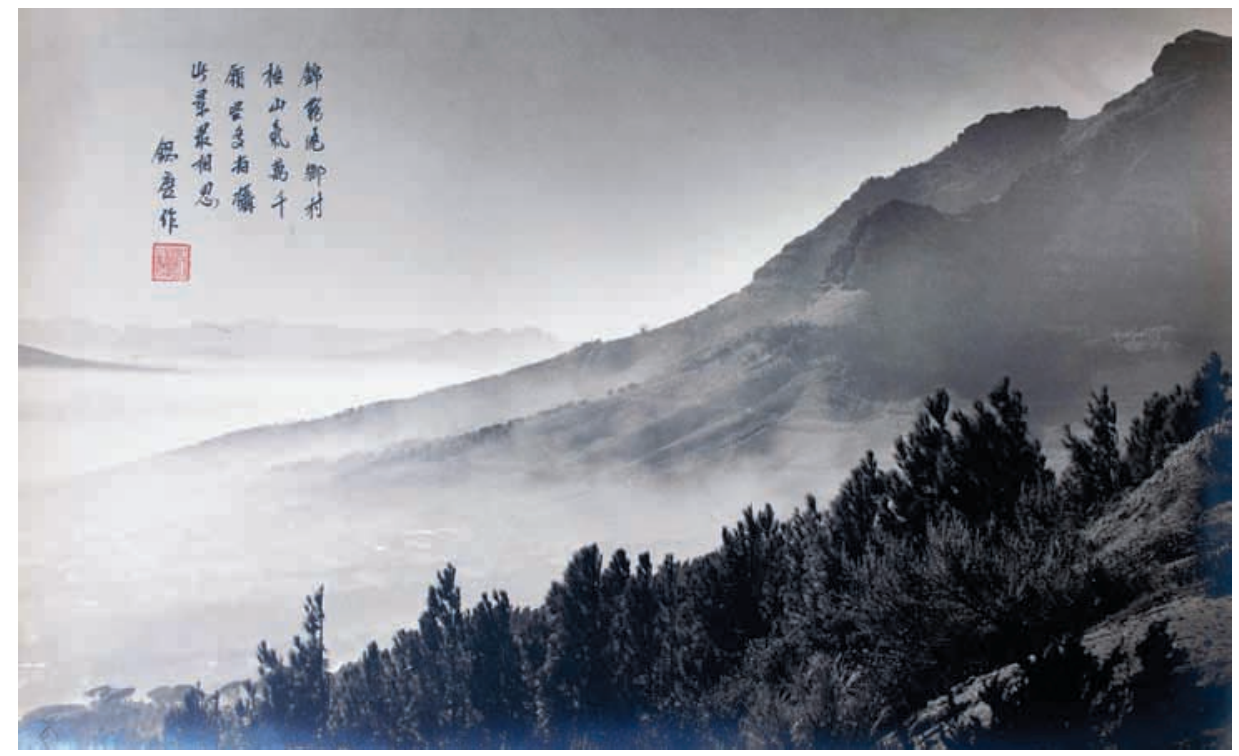

5 Tony Yau. Distant Mist. Date unknown. Photo: () Tony Yau. Courtesy of Tony Yau

6 Jack Ho. Wintry Desolation. 1954. Photo: () Jack Ho. Courtesy of Jack Ho

majority did not return to China and made their living in South Africa as merchants and traders. The vast majority of club members lived in the Transvaal province, in particular Johannesburg and Pretoria, where, by the 1950s, the Chinese South African community numbered around 3,00o people (Yap and Man 1996:330). Many club members were born in South Africa and were secondor third-generation Chinese South Africans. However, others were born in China and emigrated to South Africa in their teenage years. ${ }^{4}$ Following the election of the National Party in 1948, the discrimination suffered by Chinese South Africans consolidated and intensified. Under the Population Registration Act of 1950, Chinese South Africans were reclassified as "coloured." They were subsequently defined as "any person who in fact is, or is generally accepted as a member of a race or tribe whose national home is in China" (Yap and Man 1996:317). On the basis of these classifications, they were subject to discriminatory treatment under a range of legislation that governed where they could live, prevented them from owning property, and restricted their access to education, employment, healthcare, public facilities, and entertainment (Yap and Man 1996:318). They were often classified as belonging to different racial classifications under different legislation, which meant that they were often subject to bureaucratic confusion and inconsistent treatment under the law (Jung Park 2008:34). Although Chinese South Africans were later singled out for concessions from the 1970s onwards, throughout the apartheid era they were treated as foreigners and second-class citizens. This unique political context explains why they looked to Chinese painting for visual conventions with which to express their own visions of the South African landscape and also explains their positioning in relation to local landscape genres.

\section{THE FORMATION, ACHIEVEMENTS AND ACTIVITIES \\ OF THE CHINESE CAMERA CLUB OF SOUTH AFRICA}

The CCCSA was established in Johannesburg in 1952 by a keen amateur photographer named Jack Ho (Fig. 1). Ho had been interested in art and photography from a young age. In the early 1950 s he applied to study photography at a technical col- lege in Johannesburg but was rejected on the grounds of race. In order to circumvent this barrier to photographic education, he established a camera club in 1952 with a small group of friends and served as president. ${ }^{5}$ The club held monthly meetings at members' homes or business premises. These meetings provided a forum for the members to critique each other's prints and exchange photographic knowledge and information. The group staged their own exhibitions and participated in exhibitions staged by other photographic societies in South Africa. They also submitted their prints for inclusion in international exhibitions and won international recognition. Eight club members were elected Associates of the Royal Photographic Society

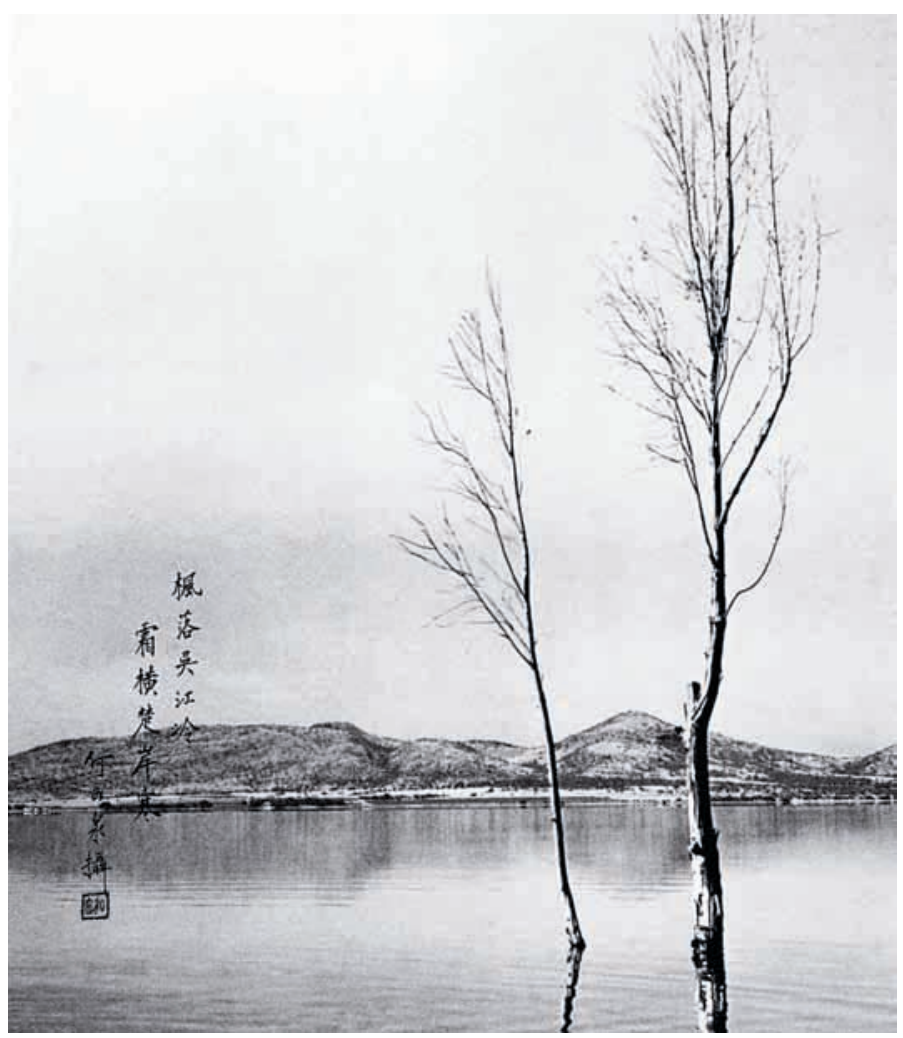




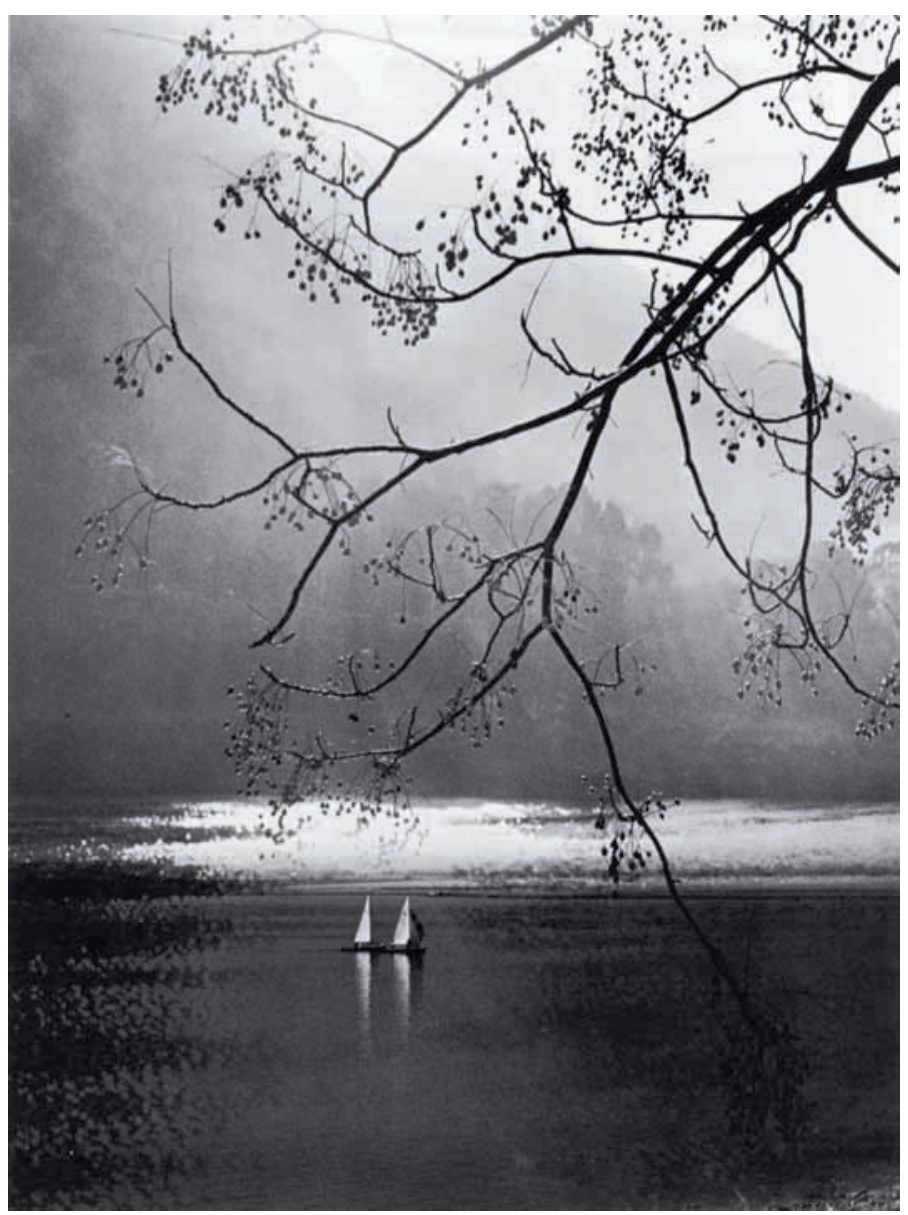

of Great Britain. In 1965, the Photographic Society of America's Who's Who in Pictorial Photography listings ranked Wing Shung Lau, a member of the CCCSA, as the eleventh most successful pictorialist photographer in the world (Downs and Kimball 1966:48). They won the respect and admiration of pictorialist photographers in South Africa and were credited by Dr. Bensusan with bringing a fresh perspective to pictorial photography in the 1950s (Bensusan 1966:95).

One of the central activities of the club was the weekly photographic outing. They would meet very early on Sunday morning in Johannesburg's Chinatown. From there, they travelled together to a prearranged destination, usually by car. ${ }^{6}$ Often the destination was within or around Johannesburg and Pretoria. However, the countryside and mountain ranges of South Africa proved the most popular and memorable destinations, and they featured regularly as the subject of the club members' landscape photographs. The Eastern Transvaal was popular, due to its close proximity, as well as the Vaal River and the Hartbeespoort Dam. On other occasions the group organized more ambitious outings, often staying for a few nights in locations that included the Drakensburg Mountains, Swaziland, and Cape Town.7 Usually these occasions were documented for posterity in photographs and cine films (Figs. 2-3).

Due to the restrictions placed upon individuals classified as Chinese under apartheid, many of these outings technically required club members to obtain permits in order to travel
7 Lai Wing. Calm Sailing. ca. 1967. Photo: () Lai Wing. Courtesy of Teddy Lai

8 Tony Yau. Tranquility. Date unknown. Photo: () Tony Yau. Courtesy of Tony Yau between provinces. From 1913 until the 1970s Chinese South Africans were required to obtain a permit for interprovincial travel, although this was not strictly enforced (Yap and Man 1996:350). It is not clear whether the club obtained permits for photographic outings. However, it is clear that domestic tourism by "non-Europeans" in the apartheid period was not encouraged, either by state policies or by the promotional material published and disseminated by the South African Railway and Tourist Board. Furthermore, certain provinces were considered completely off limits for club outings. ${ }^{8}$ In 1891 a law had been passed that forbade Chinese South Africans from living in the Orange Free State, and those passing through en route to other provinces had to be in and out within seventy-two hours (Yap and Man 1996:73). Overall, however, membership in the CCCSA enabled Chinese South Africans to travel more freely and with greater confidence to parts of South Africa where they were not guaranteed a warm reception. The organizational rubric of the club also allowed members to negotiate access to accommodation and tourist facilities that might otherwise have been denied to them. For example, one interviewee recalled an occasion when the club was turned away by the proprietor of a hotel near Harrismith that didn't accept Chinese South African guests. Members of the club photographed the hotel, and some of these photographs were later published in a photographic journal. After the proprietor saw these prints, they were subsequently allowed to stay there. ${ }^{9}$ 
After spending their Sundays taking photographs, club members would spend weekday evenings developing prints in makeshift darkrooms. The aim was to craft prints that might stand a chance of winning the monthly print competition at club meetings or being exhibited in photographic salons at home and abroad. This process involved technical knowledge and creativity, whether in the use of enlargers, the selection of appropriate photographic paper, or arranging of multiple negatives to create combination prints. Figure 4 shows a club member proudly displaying his collection of prints in what could be his home, or the home of another member.

\section{APPROPRIATION AND IDENTIFICATION IN LANDSCAPE PHOTOGRAPHS PRODUCED BY MEMBERS OF THE CHINESE CAMERA CLUB OF SOUTH AFRICA}

Some of the most intriguing prints produced by CCCSA members were photographs of the South African landscape that appropriated conventions associated with Chinese landscape painting. These highlight the Chinese Camera Club's aim of photographing the South African landscape in a "Far Eastern Mood" (Grundlingh 2001:35). One of the distinctive features shown in many of these landscape photographs is the use of Chinese cal-

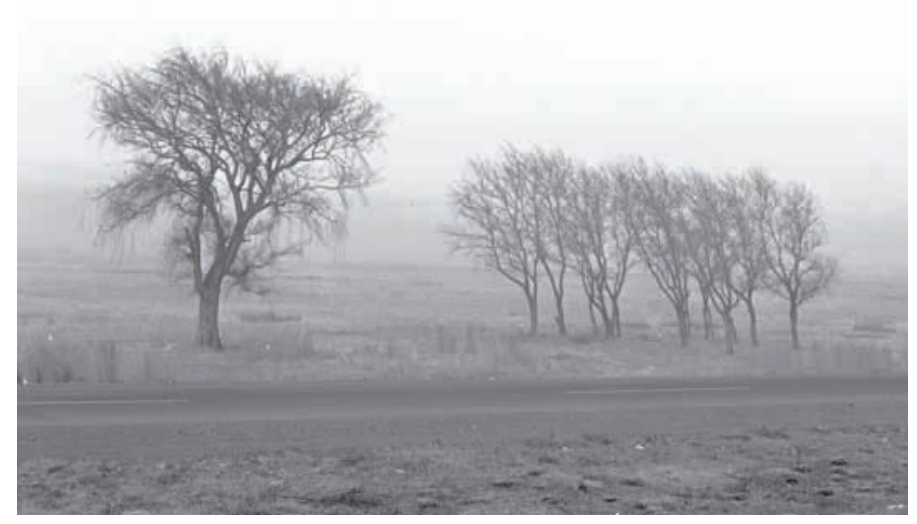

ligraphy. An example can be seen in Tony Yau's print Distant Mist (Fig. 5), which depicts Devil's Peak in Cape Town. Yau would have taken the photographic negative on a club outing, then later enlarged and printed the photograph, and finally inscribed the calligraphy onto the surface of the print with ink. Yau often used calligraphy to inscribe poems on his prints, composing the poems after the photographs had been taken. ${ }^{10}$ In other photographic prints, the calligraphy recorded the title of the print and/ or the name of the photographer. In all cases they included what interviewees called their "chop" - a signature seal stamped with red ink. ${ }^{11}$ Calligraphy was also used as a compositional device. In Jack Ho's print Wintry Desolation (Fig. 6), the inclusion of calligraphy in the lower left corner of the print counterbalances the weight of the two trees on the opposing side of the frame, leading to a harmonious composition.

It may seem difficult to imagine that the landscapes surrounding Johannesburg were easily transmutable into the monumental, idealized landscapes of Chinese landscape painting. However, CCCSA members employed ingenious and creative devices to create idealized photographic representations. Darkroom manipulation was used to create harmonious compositions redolent of Chinese landscape painting. In order to create the print Calm Sailing (Fig. 7), Lai Wing combined several negatives in the enlarger, so that areas of each were projected onto segments of the photosensitive paper during development. In so doing, he created a composite image of a hanging branch framing a tranquil lake scene. ${ }^{12}$ The boats in the photograph counterpoint the formal landscape composition. This reference to a human scale echoed the conventions used within Chinese classical painting of landscapes which were positioned by a human figure, dwelling place, or boat.

Such creativity was mirrored in the production of Tony Yau's Tranquility (Fig. 8). This physically constructed scene featured the arrangement of elaborate miniature models in an idealized composition. This shows the extent of the artifice CCCSA members pursued in order to create landscape photographs that asserted conventions associated with Chinese landscape painting. This photograph was an example of a subgenre within pictorialism more generally called "table top photography." While "table top photography" was not widely practiced within the club, such photographs show how club members also dedicated
9 W. Shung Lau. Early Morn. Date unknown. Photo: () Wing Shung Lau. Courtesy of Wing Shung Lau

10 W. Shung Lau. Cold and Grey. ca. 1965. Photo: () Wing Shung Lau. Courtesy of Wing Shung Lau

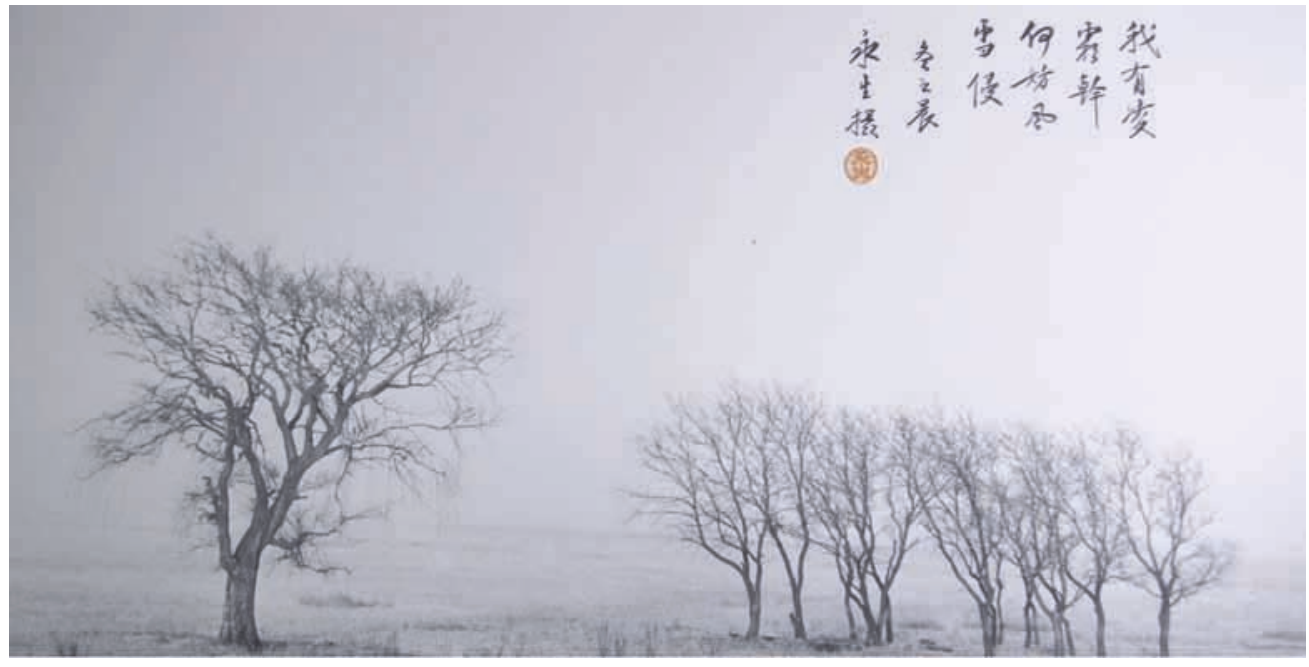




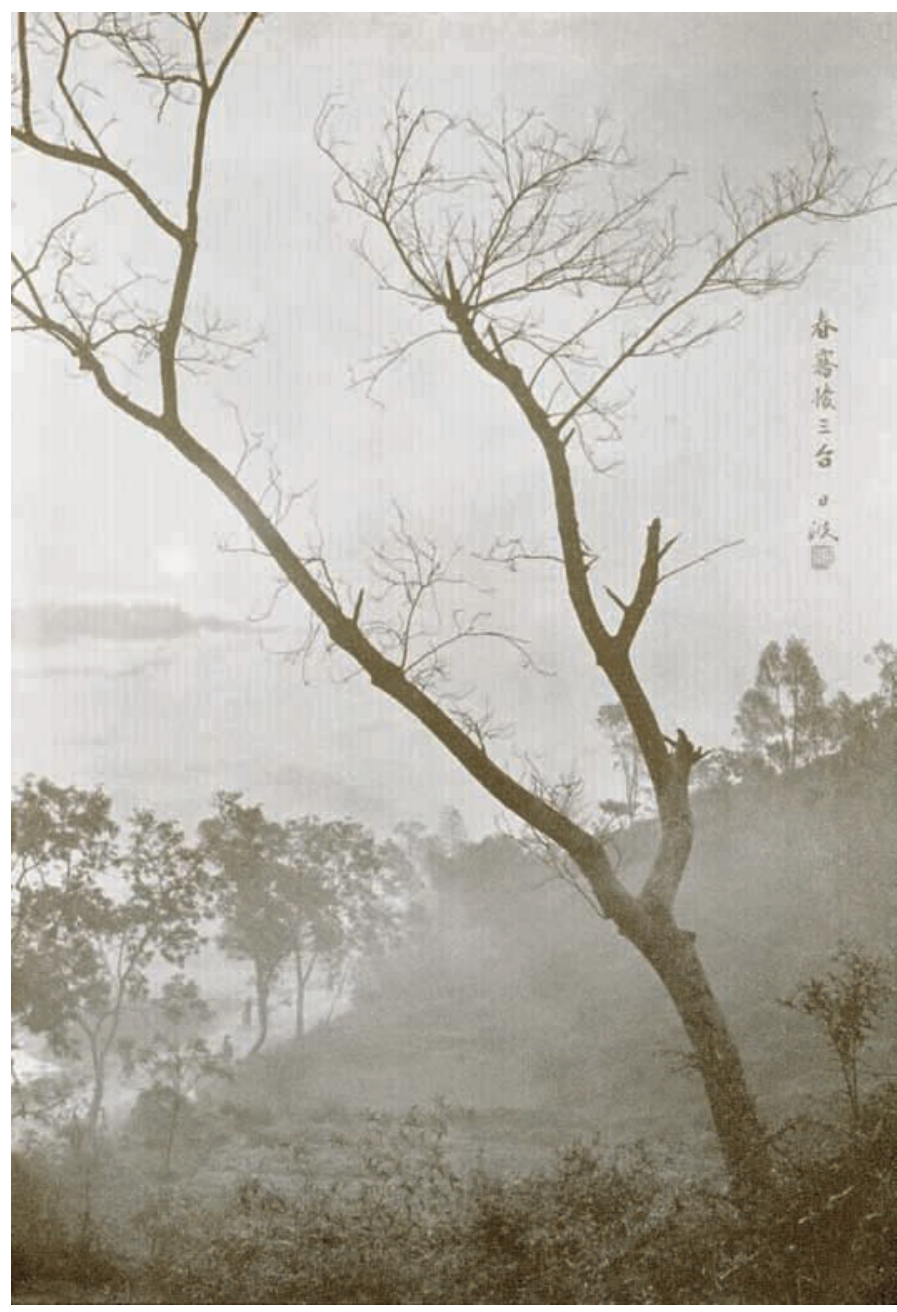

free time at home or at work to pursue their interest in creating photographs of idealized landscapes, even when the demands of everyday life and earning a living prevented them from travelling to dramatic mountain ranges and rural locations.

Sometimes prints were produced collaboratively. When W. Shung Lau was a junior member of the club, he was taken under the wing of a senior member named Au Chi Bin, the Club's Chinese Secretary. He was in contact with photographers in China, Hong Kong, and the wider Chinese Diaspora. ${ }^{13} \mathrm{Au}$ Chi Bin took Wing Shung Lau on an early morning outing to a location with some dead trees close to Johannesburg. Here, they took photographs together. W. Shung Lau made an initial print and took it to show Au Chi Bin (Fig. 9). Au Chi Bin took one of the prints away with him and returned with a cropped version. He also wrote a poetic verse and stamped the print using W. Shung Lau's signature chop, which he had left a space for (Fig. 10). ${ }^{14}$ This highlights the collaborative nature of the club, how members were educated through mentorship networks, and how a collective approach to landscape photography emerged.

Such approaches to landscape photography were as much influenced by pictorial photography in Hong Kong and the Chinese Diaspora as Chinese painting itself. In the 1950 s and 1960 s Hong Kong photographers were considered by many as the leading pictorial photographers of the world. ${ }^{15}$ They were

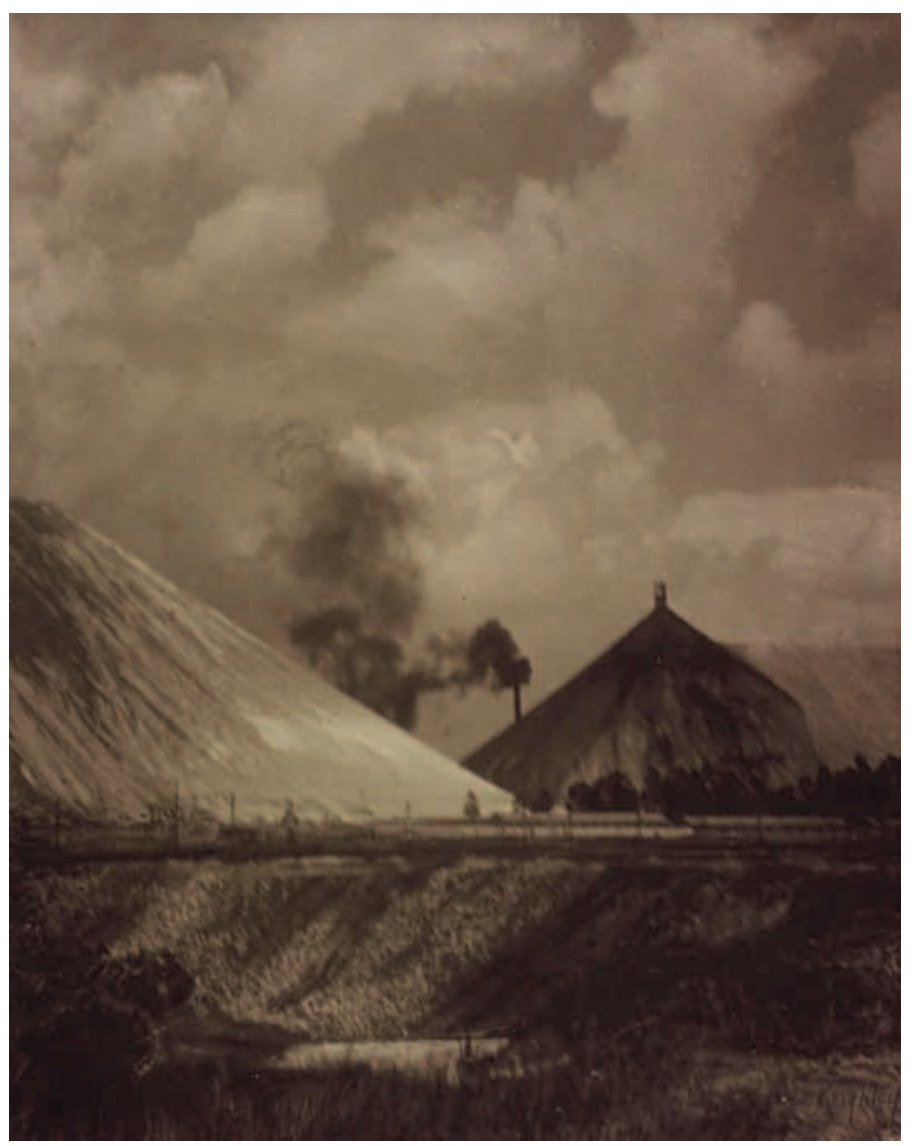

11 Yet-Pore Pun. The Morning-Mist at Toi-Shan. Date unknown.

Photo: () Yet-Pore Pun

$$
\begin{aligned}
& 12 \text { Alexander Keighley. Mine Dumps, Johannesburg. } \\
& 1939 . \\
& \text { Photo: Courtesy of the Royal Photographic Society / } \\
& \text { National Media Museum /Science \& Society Picture } \\
& \text { Library. }
\end{aligned}
$$

certainly the most successful in terms of salon acceptances. In 1966, for example, nine of the top ten leading monochrome photographers in the world were from Hong Kong (Bohlen and Kimball 1967:52). The CCCSA identified particularly strongly with these photographers. They also had direct contact with key figures in the pictorial scene in Hong Kong. For example, Dr. Hsu, a former president of the Photographic Association of Hong Kong, made two visits to South Africa in 1961 and 1964, during which he met with club members and officials (Bensusan 1966:95). The CCCSA was keen to publicly associate itself with such prestigious photographers from Hong Kong and the wider Chinese diaspora. They organized a one-man exhibition at the Orrco Theatre in Johannesburg showcasing the work of the prominent Hong Kong pictorialist Yet-Pore Pun (Chinese Camera Club of South Africa n.d.:1-4). ${ }^{16}$ One of the photographic prints included in this 


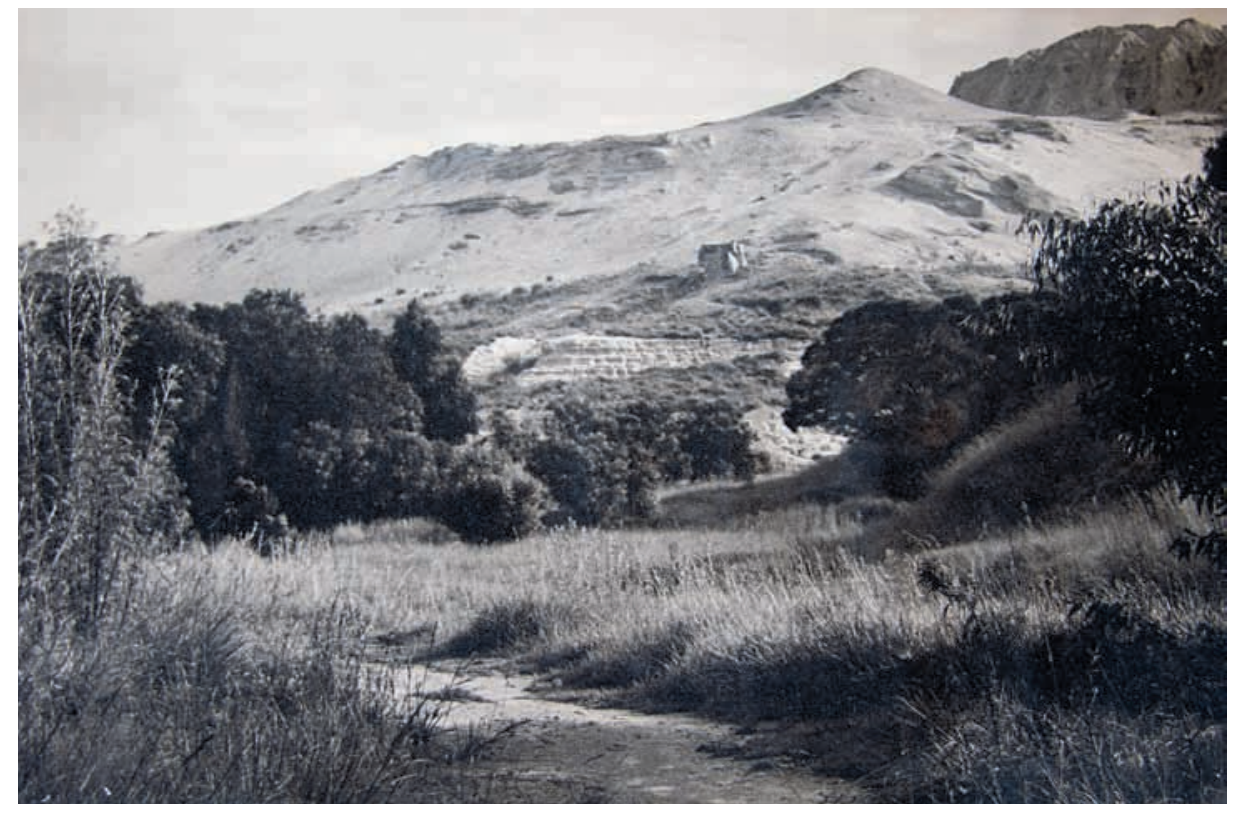

13 Tony Yau. Country Scene. Monochrome print. ca. 1965.

Photo: (c) Tony Yau. Courtesy of Tony Yau

exhibition, entitled The Morning Mist at Toi-Shan (Fig. 11), also draws on conventions associated with Chinese landscape painting and shows certain similarities to individual prints produced by CCCSA members. Like Jack Ho's Wintry Desolation (Fig. 6) and Lai Wing's Calm Sailing (Fig. 7), Yet-Pore Pun's print uses the silhouette of a threadbare tree as a compositional device, and similarly, Tony Yau's Distant Mist (Fig. 5) depicts a landscape of hills receding in mist and makes use of Chinese calligraphy as a compositional device.

This could be interpreted as evidence that CCCSA members were simply appropriating approaches to photography that originated from outside of South Africa, and that in this sense they are not truly "South African" and instead reveal more about contemporaneous trends in pictorial photography. However, the popularity of this approach to landscape photography within the club cannot be explained without reference to the local historical situation in South Africa: it was local circumstances and experiences that led CCCSA members to look elsewhere. What I am suggesting is that part of the reason that club members chose to convey their attachment to China through photography was because of their unwelcome treatment in apartheid South Africa.

Yoon Jung Park (2008) has studied the construction of Chinese South African identity during the apartheid era. Park (2008:70) argues that, in treating the Chinese community as "foreigners and second class citizens," the apartheid state prevented second- and third-generation immigrants from identifying as South African. At the same time, an idealized image of a great, mythical China took hold in the Chinese South African imagination (Jung Park 2008:75). By subscribing to essentialized notions of Chinese superiority and civilization, Chinese South Africans developed an identity that allowed them to "survive apartheid with their heads held high" (Jung Park 2008:7). One could argue that, by drawing on conventions associated with Chinese landscape painting, individual members of the Chinese Camera Club were giving visual expression to an identity that allowed them to resist the denigrations of apartheid and secure a sense of belonging in an uncertain and difficult time. Similarly, it situated them as both "belonging" yet autonomous within the geographic and spatial coordinates of a South African landscape that was coercively regulated by the apartheid state.

It is worth considering the poem recorded on Tony Yau's Distant Mist (Fig. 5) in more detail. The calligraphy reads:

錦霧繞山村,

Beautiful fog surrounds this mountain village,

\section{口山气万千。}

[...] mountain has a magnificent and changing prospect. [There is an illegible character in front of "mountain" which is probably the name of the mountain]

\section{願君多拍攝,}

I hope you can take lots of pictures [of it]

\section{山景最相思。}

Mountain scenery is most evocative of fond memories [of hometown, or China].

\section{looks like 锶 $\mathrm{Si}$ ] Tang' ${ }^{17}$}

] 唐作 Written by [first character of name illegible,

The final line, "Mountain scenery is most evocative of fond memories [of hometown, or China]," is significant. It highlights that a possible motivation for utilizing conventions associated with Chinese landscape painting was to express feelings of belonging to or yearning for China, which implicitly suggests an accompanying sense of displacement in South Africa. Such sentiments can easily be understood as a product of the apartheid state's treatment of Chinese South Africans as foreigners and second-class citizens. And yet the poem also references a specific mountain in South Africa. Furthermore, by encouraging future photographs to be taken, the poem refers to the regularity of club outings across South Africa. In this sense, the poem encapsulates how photography expressed a sense of belonging that was simultaneously international and local. 
14 F.M. Lang. Tafelberg. Monochrome print. ca. 1963.

Photo: () F.M. Lang. Courtesy of Edmund Lang

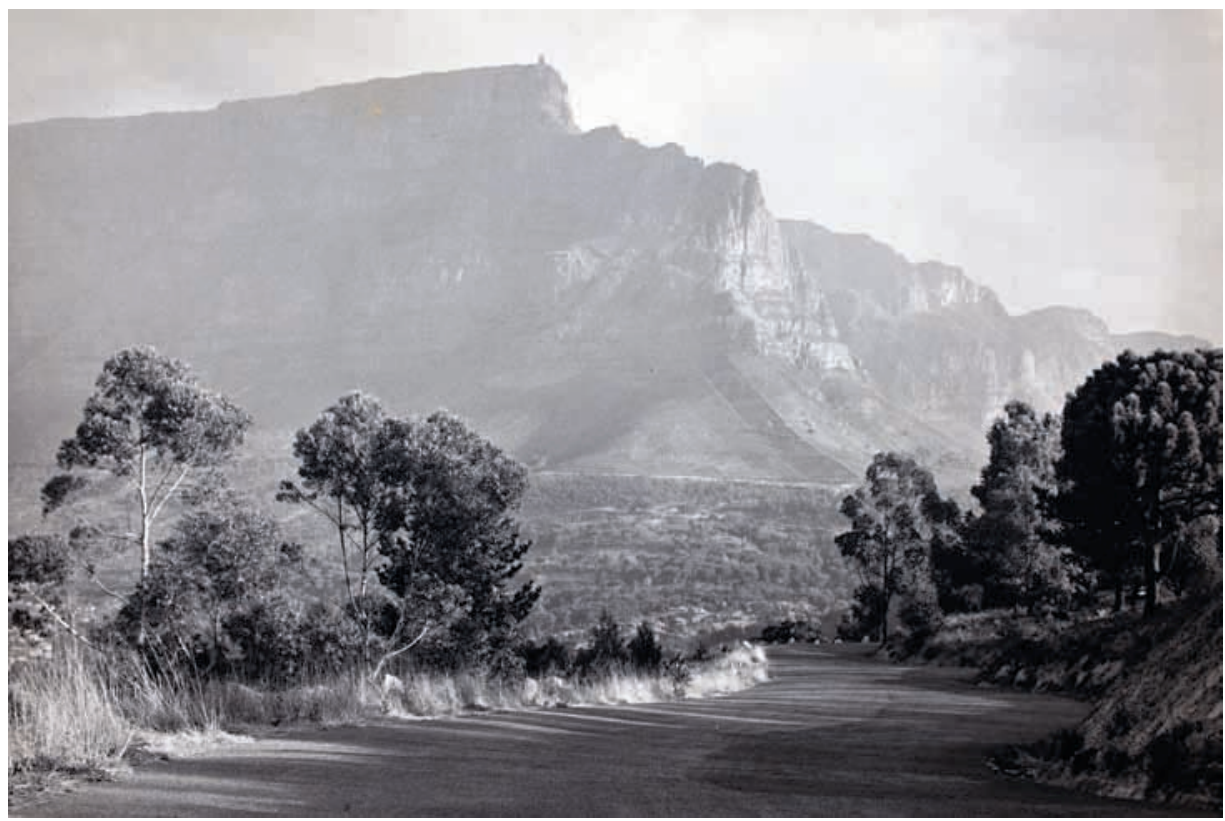

\section{MASTERING LOCAL SOUTH AFRICAN APPROACHES TO}

\section{LANDSCAPE PHOTOGRAPHY: COMPETITION AND BELONGING}

This concurrently local sense of attachment and belonging to South Africa can be found in a number of landscape photographs produced by club members. Such images also suggest how the CCCSA managed to create a platform on which to compete with white-dominated clubs and societies on an equal footing. As well as producing landscape photographs that appropriated and transformed conventions of Chinese landscape painting, club members displayed their interest and proficiency in a number of local styles of pictorialism that developed in South Africa. In particular, club members participated in a style of landscape pictorialism that was unique to Johannesburg and the mining towns of the rand. This approach was well established by the time the CCCSA had formed and was practiced by a number of photographers who belonged to the various white-dominated clubs and societies in the Johannesburg region. This approach incorporated mining and other industrial infrastructure within and surrounding Johannesburg into conventions of landscape pictorialism. Dr. Bensusan produced a number of images in this mould. In particular, the mine dumps surrounding Johannesburg-mounds of waste material left over from the mining process once the valuable minerals had been extracted-became a particularly iconic subject for local pictorialists. These bleached piles of crushed rock are strongly associated with Johannesburg's history and identity. They also provided a striking subject for visiting international photographers. Mine Dumps, Johannesburg (Fig. 12) was a print produced from a photographic negative taken by Alexander Keighley (1861-1947) during a trip to South Africa in 1939. Keighley was one of the most celebrated and influential figures in British pictorialism. On this trip, Keighley acted as an ambassador for the major photographic organizations of the United Kingdom and visited photographic societies and camera clubs across the major towns and cities of South Africa, including Johannesburg (Hankey 1947:12). It seems likely that he was chaperoned around Johannesburg by local pictori- alists and that these guides took him on a photographic trip to this particular mine dump. This shows the extent to which such subject matter had become a canonical subject for South African pictorialists in the Transvaal by 1939.

CCCSA members also participated in and developed this photographic genre. At first glance, the title and visual content of Country Scene by Tony Yau suggests a serene rural landscape (Fig. 13). However, on closer inspection, we can see Johannesburg's characteristic mine dumps emerging in the top third of the photographic plane. The winding path, soft tones, and attention to the effects of light are evocative of the peaceful and restorative effects of an outdoor stroll. Such associations might seem antithetical to the industry and commerce signified by the mine dumps. However, this romantic treatment of industrial subject matter can also be read as an expression of civic pride and attachment. Such an expression could also be linked to the CCCSA's objective of increasing the visibility of their community through domestic and international photographic recognition, as a means of announcing their community's presence and participation in Johannesburg. As club president and founding member Jack Ho stated in 1999, "We placed photography above the embarrassment and humiliation felt by ethnic minorities to make our presence visible" (quoted in Grundlingh 2001:35).

On occasion, CCCSA members also photographed iconic national sights beyond the surrounds of Johannesburg. For example, Table Mountain features in a number of photographs by club members. Figure 14 shows a monochrome print by F.M. Lang entitled Tafelberg. There exists more than one photograph of this aspect of Table Mountain taken by a number of club members, from slightly different angles and with different tonal values. This congruence suggests it was taken on a club outing.

Lang's Tafelberg can be linked to domestic trends in South African pictorialism. Michael Godby (2013a:159) has argued that South African pictorialists in the first half of the twentieth century used landscape photography to express their patriotism as well as South African values and identities. Tafelberg, with its 


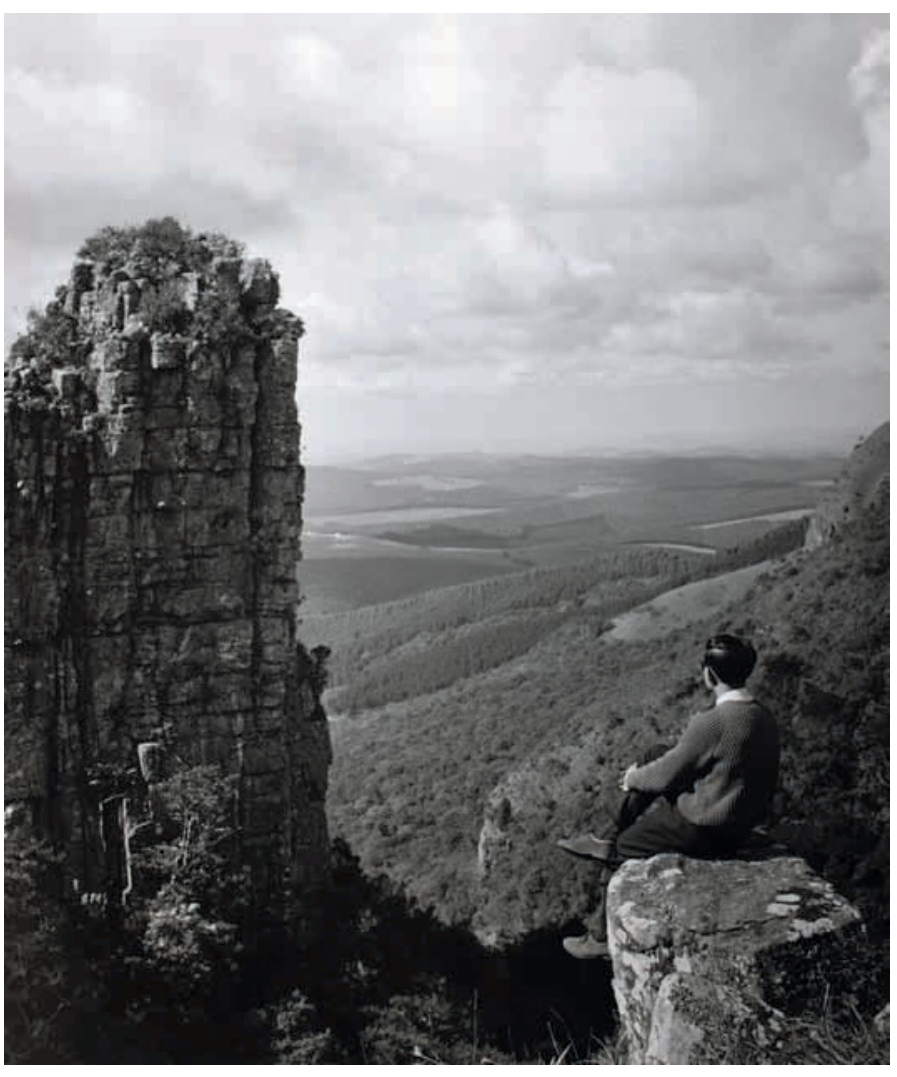

use of an S-curve composition to draw the viewer's eye along the winding road towards the towering mountain, certainly conveys and celebrates the monumentality of this national icon. The title used the Afrikaans word for "table mountain" and, as such, highlights how club members referenced and appropriated aspects of a range of South African identities (possibly Afrikaans-speaking and so-called coloured communities) beyond their own.

Such images underscore how club members aimed to express a sense of patriotic attachment to South Africa, despite the exclusion, hardship, and discrimination they suffered there. However, in engaging with national trends in pictorial pho- tography, CCCSA members were also motivated by a desire to compete with other South African photographic societies and clubs. In proving their mastery of a range of landscape genres, they sought to demonstrate their superiority to local white-dominated camera clubs and photographic societies. This argument is supported by the ways in which such photographic prints circulated. Tafelberg was accepted by and hung in the $16^{\text {th }}$ Witwatersrand International Salon of Photography in Johannesburg in 1963 (Witwatersrand International Salon of Photography 1963:7). This highly competitive salon, organized by the Camera Club of Johannesburg, was a fixture of the annual salon scene in South Africa and received print and color slide submissions from across South Africa and the world. One could speculate that F.M. Lang perhaps chose to submit this particular photographic print as it conformed to accepted ways of treating photographic prints and accepted subject matter. In other words, club members produced work for competitions in a range of established South African landscape genres in order to meet the expectations and prejudices of the salon judges. They did this in order to maximize their chance of salon success and to out-compete other local pictorialists across a range of domestic and international salons.

CCCSA members also used the photographic device of the figure in the landscape to establish their presence in South Africa. Cigar Rock by F.M. Lang (Fig. 15) depicted a Chinese South African, most likely a fellow club member, sitting on a cliff face, gazing out over a dramatic and picturesque mountain scene. The inclusion of a Chinese South African figure interrupts and challenges received notions about who the landscapes of South African belonged to, who belonged within them, and about who was entitled to appreciate their grandeur. It exposed and challenged hierarchies of belonging and mobility in South Africa. By situating the body in the landscape, the photograph establishes a reciprocal relationship between the two and asserts the right of Chinese South Africans to appreciate (and indeed situate themselves) within South Africa's national beauty in spite of the travel restrictions and exclusions from discourses of national identity that they were subject to. An untitled color slide photograph by
15 F.M. Lang. Cigar Rock. Monochrome print. Date unknown.

Photo: ( ) F.M. Lang. Courtesy of Edmund Lang

16 F.M. Lang, Untitled. Color transparency. ca. early 1960s.

Photo: () F.M. Lang. Courtesy of Edmund Lang

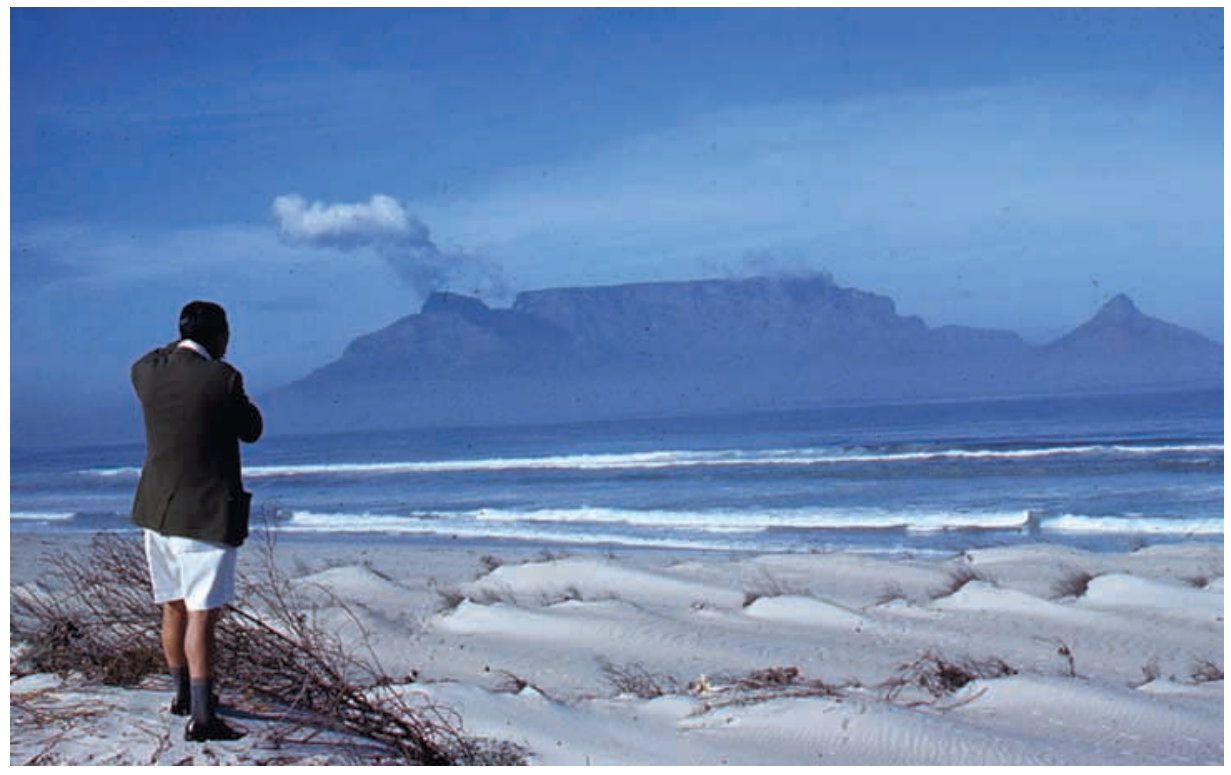


F.M. Lang (Fig. 16) shows a club member, possibly Jack Ho, taking a photograph of Table Mountain from the vantage point of Bloubergstrand. By depicting this specific act of taking a photograph, this image commemorates the club's photographic pilgrimages to quintessentially South African landscapes. In doing so, this photograph inscribes the CCCSA's-and by extension the wider Chinese South African Community's-presence in South Africa and their entitlement to share in its natural heritage.

\section{CONCLUSION}

The landscape photographs discussed here resist easy categorization. They also do not conform to essentialized notions of the "African" photographer. Firstly, the photographs demonstrate that photographers based in Africa often articulated multiple ideas of belonging and configurations of identity that were simultaneously local and international. In pioneering a distinctive approach to photographing the South African landscape and participating in international photographic networks, CCCSA members articulated the importance of their ongoing relationship_both real and imagined-with China. This relationship functioned as a source of pride in the face of apartheid-era discrimination. At the same time, by mastering a range of local approaches to landscape photography and by including fellow club members within their landscape photographs, individual photographers expressed a simultaneous sense of belonging to South Africa. This engagement with local landscape genres was also a means of establishing a platform to compete with whitedominated photographic societies and camera clubs on equal terms. In this sense, landscape photography was a means of obtaining visibility, of making their presence known through representing their local and outlying environments by referencing their own bodily navigation of apartheid South Africa, and by out-competing fellow pictorialist photographers. The organizational rubric of the camera club provided a forum for photographers to express individual and collective configurations of identity in ways that rejected repressive apartheid classifications and instead reflected how they each interpreted and shaped the world around them.

MALCOLM CORRIGALL is a doctoral student at the School of Oriental and African Studies, where he is completing his thesis on the history of the Chinese Camera Club of South Africa. He has previously published an article in the journal Safundi (Volume 15, Issue 2-3, 2014) that focused on landscape photographs by Cedric Nunn and Sabelo Mlangeni. malcolm.corrigall@googlemail.com.

\section{Notes}

This article is dedicated to the memory of Jack Ho, Tony Yau, Wing Shung Lau, and Cecil King, who passed away in 2014, and to Ou Shue, who passed away in 2015. I am greatly indebted to them, as well as to the other CCCSA members and members' relatives that I spoke to, for their kindness and generosity and the information and assistance they provided during the course of my PhD research.

1 In this article, I concentrate on photographs produced by a small number of club members. In my forthcoming doctoral thesis I will examine the work of a larger number of club members. Although the Chinese Camera Club of South Africa was renowned in the 1950 s and 1960 s for their distinctive approach to landscape photography, its members had diverse interests and produced photographs in a range of different genres. The thesis will consider all aspects of their photographic output and examine the historical trajectory, achievements, and activities of the club in the historical context of apartheid South Africa.

2 Newbury has identified photographic studios as one of the most promising avenues for future research, as well as calling for scholars to reconsider familiar archives of South African photography from new perspectives.

3 Interview with Jack Ho, February 4, 2014, Vancouver.

4 Interview with Tony Yau, April 23, 2014, Johannesburg.

5 Interview with Jack Ho, February 4, 2014, Vancouver.

6 Interview with anonymous research participant, September 26, 2013, Johannesburg.

7 Various interviews with former club members and relatives, from September, 2013 onwards.

8 Interview with Jack Ho, February 4, 2014, Vancouver.

9 Interview with anonymous research participant, September 26, 2013, Johannesburg.
10 Interview with Tony Yau, April 13, 2014, Johannesburg.

11 Email from W. Shung Lau, February 28, 2014.

12 Email from Teddy Lai, July 23, 2013.

13 Interview with Jack Ho, February 4, 2014, Vancouver.

14 Email from W. Shung Lau, February 28, 2014.

15 Interview with anonymous research participant, September 26, 2013, Johannesburg.

16 Interview with Jack Ho, February 4, 2014, Vancouver.

17 Translation by Biqing Ouyang, December 20, 2014.

\section{References cited}

Bensusan, A. D. 1966. Silver Images: History of Photography in Africa. Cape Town: H. Timmins.

Bohlen, Roy J., and Richard B. Kimball. 1967. "Who's Who in Pictorial Photography-1966 Monochrome Prints." PSA Journal 33 (5):51-54.

Chinese Camera Club of Johannesburg. n.d. Salon Catalogue of the Distinguished Work of Yet-Pore Pun. Johannesburg: The Club.

Downs, Richard F., and Richard B. Kimball. 1966. "Who's Who in Pictorial Photography, 1965-Monochrome Prints." PSA Journal 32 (5):47-51.

Godby, Michael. 2013a. "A Short History of Landscape Photography." In Transition, ed. Les Recontres Des Arles and Market Photo Workshop, pp. 158-63. Paris: Édition Xavier Barrell.

.2013b. “Native Studies': Photographic Responses to the 'Native Question' in South Africa around the Middle of the Twentieth Century." In The Rise and Fall of Apartheid: Photography and the Bureaucracy of Everyday Life, ed. Okwui Enwezor and Rory Bester, pp. 46-65. Munich: Prestel.
Grundlingh, Kathleen. 1999. “The Development of Photography in South Africa." In Anthology of African and Indian Ocean Photography, ed. Revue Noire, pp. 243-52. Paris: Revue Noire. 2001. "Pictorialism and the Salon in South Africa, 1906-1960." In Lines of Sight, ed. Kathleen Grundlingh, pp. 34-49. Cape Town: South African National Gallery.

Hankey, J.L. 1947. “The Man and His Methods.” In Alexander Keighley, Hon. F.R.P.S.: A Memorial, ed. The Pictorial Group of the Royal Photographic Society of Great Britain, pp. 7-20. London: Royal Photographic Society of Great Briatin-Pictorial Group.

Jung Park, Yoon. 2008. A Matter of Honour: Being Chinese in South Africa. Auckland Park: Jacana Media.

Mnyaka, Phindeswa. 2014. "From Salons to the Native Reserve: Reformulating the 'Native Question' through Pictorial Photography in 1950 s South Africa." Social Dynamics: A Journal of African Studies 40 (1):106-21.

Newbury, Darren. 2013. "Sizwe Bansi and the Strong Room of Dreams: Photographic Histories After Apartheid." In The Rise and Fall of Apartheid: Photography and the Bureaucracy of Everyday Life, ed. Okwui Enwezor and Rory Bester, pp. 226-33. Munich: Prestel.

Nordström, Alison, and David Wooters. 2008. "Crafting the Art of the Photograph.” In TruthBeauty: Pictorialism and the Photograph as Art, 1845-1945, ed. Thomas Padon, pp. 33-49. Vancouver: Vancouver Art Gallery.

Witwatersrand International Salon of Photography. 1963. Sixteenth Witswatersrand International Salon of Photography. Johannesburg: The Camera Club of Johannesburg.

Yap, Melanie, and Dianne Leong Man. 1996. Colour, Confusion, and Concessions: The History of the Chinese in South Africa. Hong Kong: Hong Kong University Press. 